A C G

publications

Rec. Nat. Prod. 11:6 (2017) 521-531

records of natural

products

\title{
Chemical Composition and Antimicrobial Activity of the Essential Oils of Five Scrophularia L. Species from Turkey
}

\author{
Gülin Renda $^{1^{*}}$, Yalçın Kalaycı ${ }^{1}$, Büşra Korkmaz ${ }^{1}$, \\ Sengül Alpay Karaoglu ${ }^{2}$ and Nurettin Yaylı ${ }^{1}$
}

\author{
${ }^{1}$ Karadeniz Technical University, Faculty of Pharmacy, Department of Pharmacognosy, 61080 \\ Trabzon, Türkiye \\ ${ }^{2}$ Recep Tayyip Erdogan University, Faculty of Science, Department of Biology, 53100 Rize, Türkiye
}

(Received February 27, 2017; Revised May 22, 2017; Accepted May 25, 2017)

\begin{abstract}
The essential oils of the five Scrophularia species; Scrophularia chrysantha Jaub. et Spach, Scrophularia kotschyana Benth., Scrophularia olympica Boiss., Scrophularia cinerascens Boiss. and Scrophularia zuvandica Grossh. were obtained by hydrodistillation (HD) with a range of $0.10 \%$ to $0.16 \%$ yield and analazsed by GC-FID/MS. In the meantime, the volatile organic compounds (VOCs) of $S$. chrysantha, $S$. kotschyana, S. olympica, S. cinerascens and S. zuvandica were also identified with the technique of SPME GCFID/MS and the phytochemical results were evaluated. The experimental results of this study showed that the major compounds of essential oils which were taken by the hydrodistillation were carvacrol $(52.4 \%)$, 2pentadecanone (26.7\%), 2-pentadecanone (12.2\%), (Z)-2-nonenal (11.2\%) and carvacrol (69.1\%) respectively. Isovaleraldehyde $(37.1 \%, 27.9 \%)$, eucalyptol $(13.8 \%)$, 2-ethyl furan $(14.8 \%)$ and 3(Z)-hexenol $(91.3 \%)$ were respectively found as the main constituents of the five Scrophularia species with SPME method. Also antimicrobial activities of the essential oils of the five Scrophularia species were screened by using agar well diffusion method. It was identified that S. olympica, S.chrysantha, and S. kotschyana, have anti-tuberculosis activity, whereas, the essential oils gained from $S$. zuvandica and $S$. cinerascens have anti-fungal activity.
\end{abstract}

Keywords: Scrophularia; SPME GC-FID/MS; anti-tuberculosis activity; agar well diffusion. 우 2017 ACG Publications. All rights reserved.

\section{Introduction}

The genus Scrophularia L. (Scrophulariaceae) which comprise of 310 species worldwide, is represented by 66 species ( 83 taxa) in Turkey [1-4]. Scrophularia species grow mountainous regions, forests, and riversides [1]. Species of the genus Scrophularia are commonly known as figworts. Additionally, the name of the genus is reported to come from "scrofula" which is also the name of a form of tuberculosis and given to the genus because of its reported usage in scrofulous swellings [4].

\footnotetext{
* Corresponding author: E-Mail: gulingurhan@yahoo.com
} 
Some of the Scrophularia species are used as traditional medicine in Turkey for the treatment of vesicles on the skin, warts, and inflammatory skin diseases like abscess, lichen infections wounds, urticaria, bacterial-viral infections, as analgesic, antirheumatic, and antipyretic [5-10].

Despite the existence of 23 endemic species belongs to the genus of Scrophularia in Turkey, studies on the essential oil components of Scrophularia species are limited. In a study conducted in 2013, the essential oil components of the aerial parts of Scrophularia oxysepala Boiss. were determined by GC-MS analysis and phytol (25.3\%), methyl benzyl alcohol (9.3\%), dehydrodieugenol (6.7\%), methyl benzaldehyde (5.3\%) and eugenol (1.3\%) were found as the main compounds. Additionally the low level of free radical scavenging activity (RC50 value $1.852 \mathrm{mg} / \mathrm{mL}$ ) and low insecticidal activity of the volatile oil were reported [11]. In addition, the essential oil analysis on the radix of Scrophularia ningpoensis Hemsl. was also mentioned and palmitic acid (25.4\%), linoleic acid $(10.04 \%)$ and $\alpha$-linolenic acid $(6.06 \%)$ were identified as the main constituents of essential oil [12]. Seasonal variation for the essential oil of Scrophularia frigida Boiss. was compared and the essential oil of autumn sample was found to be composed of fatty acid derivatives mainly, while the essential oil of summer sample contained oxygenated monoterpenes as the major constituents [13]. Chemical composition of the essential oil of Scrophularia amplexicaulis Benth., which is a native species to Turkey, was also investigated by GC-FID/MS and the main constituents were found to be eugenol $(53.8 \%)$ and eugenol acetate $(24.5 \%)$ [14].

Our literature survey showed that no research has been performed on the volatile organic compounds of S.chrysantha, S. kotschyana S. olympica, S.cinerascens and S. zuvandica. In the light of this evidence, we planned to analyze the volatile constituents of the aerial parts of these five Scrophularia species from the flora of Turkey and to determine the possible antimicrobial effects of the essential oils of these species.

\section{Materials and Methods}

\subsection{Plant Materials}

The aerial parts of plants were collected from different locations of Turkey during the flowering stages. Voucher specimens were identified by Dr Gülin Renda and have been deposited in the Herbarium of Hacettepe University, Faculty of Pharmacy (HUEF) (Table 1). Plant materials cleaned to remove impurities and stored in air-tight container until use.

Table 1. Examined species, voucher numbers, collection data and localities of the Scrophularia species in Turkey.

\begin{tabular}{|c|c|c|c|}
\hline Species & $\begin{array}{l}\text { Voucher No. } \\
\text { (HUEF) }\end{array}$ & $\begin{array}{l}\text { Collection } \\
\text { Date }\end{array}$ & Localities \\
\hline S. chrysantha (A) & 15007 & 12.07.2015 & Trabzon Caykara, Mogalakamboz plateau \\
\hline S. kotschyana (B) & 15002 & 11.05 .2014 & $\begin{array}{l}\text { Trabzon Macka, Altindere village, Sumela } \\
\text { Monastery }\end{array}$ \\
\hline S. olympica (C) & 15020 & 11.07.2015 & $\begin{array}{l}\text { Rize Camlihemsin, Vercenik village, } \\
\text { Cicekliyayla plateau }\end{array}$ \\
\hline S. cinerascens $(\mathrm{D})$ & 15004 & 20.06.2015 & Erzurum-Pasinler road 10. Km \\
\hline S. zuvandica $(\mathrm{E})$ & 15003 & 20.06 .2015 & Erzurum Cesme, roadsides of the way to pond \\
\hline
\end{tabular}

\subsection{Isolation of the Essential Oils}

The aerial parts of the fresh Scrophularia samples $(120 \mathrm{~g}$, each) were hydrodistilled in a Clevenger-type apparatus using cooling bath $\left(-15^{\circ} \mathrm{C}\right)$ system $(4 \mathrm{~h})$. The essential oils were taken in HPLC grade n-hexane $(0.5 \mathrm{~mL})$ and kept at $4^{\circ} \mathrm{C}$ in a sealed brown vial until the use. $1 \mu \mathrm{L}$ of the essential oils were separately injected to GC-FID/MS instrument. 


\subsection{SPME Analysis}

The flowered fresh plant materials (1.0 g, each) of five Scrophularia species were analyzed with a SPME device (Supelco, USA). Plant materials were crumbled and placed in a $10 \mathrm{~mL}$ vial sealed with a silicone-rubber septum cap. A polydimethylsiloxane/divinyl-benzene coating fiber was placed to the head space and used to obtain volatile components. The SPME fibers were conditioned for $5 \mathrm{~min}$ at $250{ }^{\circ} \mathrm{C}$ in the $\mathrm{GC}$ injector. Extractions were achieved with magnetic stirring at $50{ }^{\circ} \mathrm{C}$ using an incubation time of $5 \mathrm{~min}$ and an extraction time of $10 \mathrm{~min}$. Fibers with extract of aroma compounds were subsequently injected into the GC injector. Each sample was analyzed and reported. Conditioning time for subsequent assays was set at $4 \mathrm{~min}$ of desorption after each extraction. The temperature, incubation and extraction times were set according to the reported experiment $[15,16]$.

\subsection{Gas Chromatography-Mass Spectrometry (GC-FID/MS)}

The gas chromatography-flame ionization detector (GC-FID) analysis was carried out on a Shimadzu QP2010 plus gas chromatography equipped with a flame ionization detector (FID) using a Rtx-5MS capillary column (30 m x $0.25 \mathrm{~mm}$, film thickness, $0.25 \mu \mathrm{m})$. Shimadzu QP2010 Plus gas chromatograph was coupled to a Shimadzu QP2010 Ultra mass selective detector. The fibers containing the extracted volatiles (SPME) were injected into the GC-MS injector. Split mode was employed and split ratio was 1:20. The oven program was as follows: initial temperature was $60^{\circ} \mathrm{C}$ for 2 min, which was increased to $240^{\circ} \mathrm{C}$ at $3 \mathrm{~min}$, final temperature $250^{\circ} \mathrm{C}$ was held for $4 \mathrm{~min}$. The injector and mass transfer line temperatures were set at $280{ }^{\circ} \mathrm{C}$ and $250^{\circ} \mathrm{C}$, respectively. Helium (99.999\%) was used as carrier gas with a constant flow-rate of $1 \mathrm{~mL} / \mathrm{min}$. Detection was carried out in electronic impact mode (EI); ionization voltage was fixed to $70 \mathrm{eV}$ and scan mode $(40-450 \mathrm{~m} / \mathrm{z})$ was used for mass acquisition [16].

\subsection{Compound Identification}

Retention indices of the components were determined by Kovats method using n-alkanes (C6C32) as standards. The volatile compounds were identified by comparison of their retention indices (relative to C6-C32 alkane standards) and mass spectra with those of the mass spectra of the two libraries (FFNSC1.2 and W9N11) and also confirmed by comparing the retention indices with the data published in the literature.

\subsection{Antimicrobial Activity}

All test microorganisms; Escherichia coli (E. coli) ATCC35218, Yersinia pseudotuberculosis ( $Y$. pseudotuberculosis) ATCC911, Pseudomonas aeruginosa (P. aeruginosa) ATCC43288, Enterococcus faecalis (E. faecalis) ATCC29212, Bacillus cereus (B. cereus) 709 Roma, Mycobacterium smegmatis (M. smegmatis) ATCC607, Candida albicans (C. albicans) ATCC60193 and Saccharomyces cerevisiae (S. cerevisia) RSKK 251 were obtained from Refik Saydam Hifzissihha Institute (Ankara, Turkey). All of the essential oils were weighed and dissolved in hexane to prepare extract stock solutions.

\subsection{Agar Well Diffusion Assay}

The antimicrobial effects of the substances were tested quantitatively in respective broth media by using double microdilution [17-19]. The antibacterial and antifungal assays were performed in Mueller-Hinton broth (MH) (Difco, Detroit, MI) at pH.7.3 and buffered Yeast Nitrogen Base (Difco, Detroit, MI) at $\mathrm{pH} 7.0$, respectively. The micro dilution test plates were incubated for $18-24 \mathrm{~h}$ at $35^{\circ} \mathrm{C}$. Brain Heart Infusion broth (Difco, Detriot, MI) was used for M. smegmatis, and incubated for 48-72 h at $35^{\circ} \mathrm{C}$ [20]. Antimicrobial activity was assessed by comparing the inhibition zone generated by 
essential oils against the test microorganisms with the inhibition zone generated by standard drugs. Ampicillin $(10 \mathrm{mg} / \mathrm{mL})$, streptomycin $(10 \mathrm{mg} / \mathrm{mL})$ and fluconazole $(2 \mathrm{mg} / \mathrm{mL})$ were used as standards. Dimethylsulphoxide with dilution of 1:10 was used as solvent control. The results were interpreted in terms of diameter of inhibition zone and given in Table 4.

\section{Results and Discussion}

The essential oils of S. chrysantha, S. kotschyana, S. olympica, S. cinerascens and S. zuvandica obtained by hydrodistillation in a Clevenger type apparatus produced light orange oils with a yield of $0.10 \%, 0.15 \%, 0.11 \%, 0.16 \%$ and $0.11 \%(\mathrm{w} / \mathrm{w})$, respectively. The identity, retention time, and the percentage of composition of oils obtained from the Scrophularia species are presented in table 2. The percentages of the composition are presented as relative peak area. A total of 77 compounds from the five Scrophularia species were identified and quantified, accounting from $98.6 \%$ to $99.9 \%$ ratio. Among the species studied, S. cinerascens and S. olympica were found to be the most volatile oil containing species $(0.16 \%)$, while the least volatile oil containing species was found to be S. chrysantha $(0.10 \%)$. The highest numbers of compound diversity were observed in the essential oils of both S. cinerascens and S. olympica species with 28 compounds (Table 2).

Composition of volatile organic compounds for the same five Scrophularia species were also identified by SPME with GC-FID/MS. Identifications were made on the basis of comparison of GC Kovats retention indexes (RIs) with reference to a homologous series of n-alkanes. The results of SPME analysis were compared with those obtained by HD and all of the results were given in Table 2. According to the results of the study, the major compounds identified in the SPME extracts of the five Scrophularia species were isovaleraldehyde (37.1\% and $27.9 \%$, in S. chrysantha and S. kotschyana), eucalyptol (13.8\%, in S. olympica), 2-ethylfuran (14.8\%, in S. cinerascens) and (Z)-3-hexenol (91.3\%, in $S$. zuvandica) respectively. Whereas, the most abundant component in the investigated essential oils of five Scrophularia species, were (Z)-2-nonenal (11.2\%, in S. cinerascens), carvacrol $(69.1 \%$ and $52.4 \%$, in S. zuvandica and S. chrysantha), and 2-pentadecanone (12.2\% and $26.7 \%$, in S. olympica and $S$. kotschyana), respectively as seen in table 2 .

The chemical class distribution of the volatile organic compounds for the five Scrophularia species were listed in table 3 and they were classified into eleven classes, namely monoterpene hydrocarbons, oxygenated monoterpenes, sesquiterpene hydrocarbons, oxygenated sesquiterpenes, oxygenated diterpenes, terpen related compounds, aliphatic hydrocarbons, aldehydes, ketones, alcohols and others (Table 3). Comparative chemical class evaluation in the essential oils of the studied Scrophularia species gave that aldehydes $(36.2 \%$ and $19.2 \%)$ in S. olympica and $S$. cinerascens, oxygenatede monoterpenes $(84.4 \%$ and $76.6 \%)$ in $S$. chrysantha and S. kotschyana, and ketones (29.2\%) in S. zuvandica were the main class of organic compounds, respectively. However, SPME GC-FID/MS analysis of the Scrophularia species revealed that $S$. zuvandica was mainly composed of alcohols which were consisting of (Z)-3-hexenol with in ratio of $91.3 \%$ and the major class of organic compounds for the S. olympica, S. kotschyana, and S. zuvandica was aldehydes $(61.0 \%, 61.9 \%$, and $80.3 \%)$, respectively. But, the SPME result of S.cinerascens gave the monoterpene hydrocarbons $(47.6 \%)$ as the main group of volatile organic compounds. The essential oil compositions of the Scrophularia species were evaluated and carvacrol was found to be remarkable in the essential oil of $S$. zuvandica and S. chrysantha within the ratio of $69.1 \%$ and $52.4 \%$, respectively. 
Table 2. Identified volatile organic compounds from five Scrophularia species growing in Turkey.

\begin{tabular}{|c|c|c|c|c|c|c|c|c|c|c|c|c|c|c|}
\hline Compunds & References & RI* & $\mathrm{RI}^{\mathrm{a}}$ & RT & $\begin{array}{c}\mathrm{A} 1 \\
(\%)^{\mathrm{b}}\end{array}$ & $\begin{array}{c}\mathrm{A} 2 \\
(\%)^{\mathrm{b}}\end{array}$ & $\begin{array}{c}\mathrm{B} 1 \\
(\%)^{\mathrm{b}}\end{array}$ & $\begin{array}{c}\mathrm{B} 2 \\
(\%)^{\mathrm{b}}\end{array}$ & $\begin{array}{c}\mathrm{C} 1 \\
(\%)^{\mathrm{b}}\end{array}$ & $\begin{array}{c}\mathrm{C} 2 \\
(\%)^{\mathrm{b}}\end{array}$ & $\begin{array}{c}\text { D1 } \\
(\%)^{b}\end{array}$ & $\begin{array}{c}\mathrm{D} 2 \\
(\%)^{\mathrm{b}}\end{array}$ & $\begin{array}{c}\mathrm{E} 1 \\
(\%)^{\mathrm{b}}\end{array}$ & $\begin{array}{c}\mathrm{E} 2 \\
(\%)^{b}\end{array}$ \\
\hline \multicolumn{15}{|c|}{ Monoterpene hydrocarbons } \\
\hline$\alpha$-Thujene & {$[22]$} & 931 & 931 & 12.829 & - & - & - & - & - & 4.1 & - & - & - & 0.9 \\
\hline$\alpha$-Pinene & [23] & 939 & 939 & 13.156 & - & - & - & - & - & 1.6 & - & - & - & 0.1 \\
\hline Sabinene & [24] & 978 & 977 & 14.695 & - & 2.7 & - & - & - & 10.8 & - & - & - & - \\
\hline$\beta$-Pinene & [23] & 979 & 981 & 14.891 & - & 5.3 & - & - & - & 11.7 & - & - & - & 0.2 \\
\hline Myrcene & [23] & 991 & 991 & 15.200 & - & - & - & - & - & - & - & - & 0.4 & - \\
\hline$p$-Cymene & [25] & 1022 & 1020 & 16.820 & 3.9 & - & - & - & 0.9 & 5.0 & - & - & 3.4 & 0.2 \\
\hline Limonene & [23] & 1029 & 1030 & 16.967 & - & - & 0.1 & - & - & 10.7 & - & - & - & 0.3 \\
\hline$\gamma$-Terpinene & [23] & 1062 & 1061 & 18.271 & 2.9 & - & - & - & - & 1.4 & - & - & 3.1 & - \\
\hline (E)-Sabinene & [22] & 1074 & 1069 & 18.648 & - & - & - & - & - & 2.3 & - & - & - & - \\
\hline$\alpha$-Terpinolene & [26] & 1086 & 1086 & 19.066 & - & - & - & - & - & - & 6.4 & - & - & - \\
\hline Nerol & [27] & 1228 & 1228 & 25.635 & - & - & - & - & 1.8 & - & - & - & - & - \\
\hline Geraniol & [22] & 1255 & 1256 & 26.495 & - & - & - & - & 0.9 & - & - & - & - & - \\
\hline \multicolumn{15}{|c|}{ Oxygenated monoterpenes } \\
\hline Eucalyptol & {$[28]$} & 1034 & 1035 & 17.780 & - & 3.8 & - & - & - & 13.8 & - & - & 0.6 & 0.4 \\
\hline Linalool & [29] & 1097 & 1096 & 19.910 & 19.0 & - & - & - & 9.3 & - & - & - & 9.6 & - \\
\hline Camphor & [30] & 1150 & 1149 & 22.124 & - & - & - & - & - & 0.2 & - & - & - & - \\
\hline Terpinen-4-ol & [31] & 1192 & 1191 & 23.479 & 2.3 & - & - & - & - & - & - & - & 1.0 & - \\
\hline$\alpha$-Terpineol & [29] & 1189 & 1192 & 23.981 & - & - & - & - & 2.8 & 4.6 & 2.3 & - & 0.6 & 0.2 \\
\hline$\beta$-Cyclocitral & [32] & 1220 & 1222 & 25.056 & - & - & - & - & 1.4 & - & 0.4 & - & - & - \\
\hline Carvone & [33] & 1246 & 1247 & 26.288 & 1.2 & - & - & - & - & - & - & - & 0.9 & - \\
\hline Thymol & [34] & 1290 & 1290 & 28.084 & 1.7 & - & - & - & - & - & - & - & 2.6 & - \\
\hline Carvacrol & [28] & 1299 & 1301 & 28.574 & 52.4 & - & - & - & - & - & - & - & 69.1 & - \\
\hline \multicolumn{15}{|c|}{ Sesquiterpene hydrocarbons } \\
\hline (E)-Caryophyllene & {$[23]$} & 1419 & 1418 & 33.572 & 1.6 & - & - & - & - & - & - & - & 1.0 & - \\
\hline$\beta$-Bisabolene & [24] & 1509 & 1509 & 36.695 & 1.8 & - & - & - & - & - & - & - & 1.3 & - \\
\hline \multicolumn{15}{|c|}{ Oxygenated sesquiterpenes } \\
\hline (Z)-Nerolidol & {$[35]$} & 1533 & 1532 & 37.362 & - & - & - & - & 2.1 & - & 5.4 & - & - & - \\
\hline Spathulenol & [32] & 1579 & 1577 & 39.504 & - & - & - & - & - & - & - & - & 0.3 & - \\
\hline$\alpha$-Muurolol & [32] & 1645 & 1649 & 41.600 & - & - & - & - & - & - & - & - & 0.3 & - \\
\hline
\end{tabular}

Oxygenated diterpenes 
Essential oils of five Scrophularia L. species

\begin{tabular}{|c|c|c|c|c|c|c|c|c|c|c|c|c|c|c|}
\hline Phytol & {$[28]$} & 1950 & 1949 & 51.149 & - & - & 11.5 & - & 12.0 & - & 7.9 & - & - & - \\
\hline \multicolumn{15}{|c|}{ Terpene related compounds } \\
\hline Neryl acetone & {$[26]$} & 1435 & 1438 & 34.390 & - & - & 0.3 & - & - & - & - & - & - & - \\
\hline Geranyl acetone & [29] & 1455 & 1448 & 35.216 & - & - & - & - & 1.4 & - & 2.2 & - & - & - \\
\hline$\beta$-Ionone & [29] & 1489 & 1490 & 35.801 & 1.0 & - & 0.8 & - & 4.0 & - & 2.8 & - & - & - \\
\hline$(Z, Z)$-Farnesylacetone & [26] & 1860 & 1860 & 45.139 & - & - & 1.6 & - & 1.0 & - & 1.9 & - & - & - \\
\hline \multicolumn{15}{|l|}{ Aliphatic hydrocarbons } \\
\hline 1-Octene & {$[22]$} & 794 & 796 & 8.349 & - & - & - & - & - & 2.9 & - & - & - & - \\
\hline Tetradecane & [29] & 1400 & 1403 & 32.229 & - & 0.6 & - & - & - & - & - & 1.7 & - & - \\
\hline Eicosane & [29] & 1997 & 1996 & 53.173 & - & - & 0.2 & - & - & - & 0.8 & - & - & - \\
\hline Heneicosane & [29] & 2101 & 2104 & 56.036 & - & - & 8.6 & - & 2.3 & - & 2.2 & - & - & - \\
\hline Docosane & [29] & 2200 & 2197 & 58.620 & - & - & - & - & 0.2 & - & - & - & - & - \\
\hline Tetracosane & [26] & 2400 & 2400 & 61.155 & - & - & 9.8 & - & 7.1 & - & 4.6 & - & - & - \\
\hline Pentacosane & [28] & 2500 & 2502 & 61.745 & - & - & - & - & 2.0 & - & - & - & - & - \\
\hline \multicolumn{15}{|l|}{ Aldehydes } \\
\hline Isovaleraldehyde & {$[36]$} & 700 & 697 & 5.932 & - & 37.1 & - & 27.9 & - & 3.9 & - & 13.6 & - & 1.4 \\
\hline Pentanal & [36] & 715 & 720 & 6.505 & - & - & - & 5.0 & - & - & - & 2.3 & - & - \\
\hline Tiglic aldehyde & {$[22]$} & 748 & 747 & 7.365 & - & - & - & - & - & - & - & 9.4 & 1.3 & 1.2 \\
\hline (E)-2-Pentenal & [26] & 754 & 756 & 7.584 & - & - & - & 2.2 & - & 0.6 & - & - & - & - \\
\hline Hexanal & [23] & 802 & 802 & 8.610 & 2.3 & 8.8 & - & 18.0 & - & 5.4 & - & 11.1 & - & 0.6 \\
\hline (E)-2-Hexenal & [37] & 850 & 849 & 10.181 & - & 0.1 & - & 5.3 & - & 4.6 & - & 2.0 & - & 0.1 \\
\hline Heptenal & [26] & 899 & 896 & 11.662 & - & - & - & - & 5.3 & - & - & - & - & - \\
\hline Heptanal & [38] & 906 & 905 & 11.756 & - & 1.6 & - & 2.6 & - & 0.3 & - & 1.5 & - & 0.1 \\
\hline 2,4-Hexadienal & [26] & 907 & 906 & 12.141 & - & - & - & 0.4 & - & - & - & - & - & - \\
\hline (E)-2-Heptenal & [39] & 959 & 959 & 13.878 & - & - & - & - & - & 0.1 & - & - & - & - \\
\hline Benzaldehyde & [29] & 960 & 960 & 14.422 & - & 5.6 & 3.5 & 9.5 & 2.8 & 2.5 & 3.5 & 11.0 & 1.1 & 0.9 \\
\hline Octanal & [26] & 998 & 999 & 15.723 & - & - & 0.8 & 3.2 & - & 1.6 & 4.2 & 5.8 & - & 0.1 \\
\hline$(E, E)-2,4-H e p t a d i e n a l$ & [29] & 1013 & 1013 & 16.112 & - & - & - & 0.3 & - & 0.2 & - & - & - & - \\
\hline Benzene acetaldehyde & [29] & 1045 & 1047 & 17.135 & - & 8.1 & 0.5 & 0.8 & 2.9 & 1.3 & 5.8 & 2.2 & 0.6 & 0.4 \\
\hline (E)-2-Octenal & {$[22]$} & 1049 & 1048 & 18.191 & - & - & 0.3 & - & - & - & - & - & - & - \\
\hline Nonanal & [29] & 1101 & 1101 & 20.037 & - & 0.6 & 2.7 & 5.0 & 5.5 & 3.0 & 7.8 & 2.1 & - & 0.3 \\
\hline (Z)-2-Nonenal & [26] & 1142 & 1142 & 21.485 & - & - & - & - & - & - & 11.2 & - & - & - \\
\hline Capraldehyde & [26] & 1201 & 1196 & 24.371 & - & - & - & 0.1 & 0.5 & - & 1.8 & - & - & - \\
\hline (E)-2-Decanal & [26] & 1260 & 1260 & 26.705 & - & - & 0.4 & - & 0.4 & - & 0.8 & - & - & - \\
\hline
\end{tabular}


Renda et.al., Rec. Nat. Prod. (2017) 11:6 521-531

\begin{tabular}{|c|c|c|c|c|c|c|c|c|c|c|c|c|c|c|}
\hline Undecanal & [40] & 1305 & 1302 & 28.728 & - & - & 0.2 & - & 0.4 & 0.1 & - & - & - & - \\
\hline$(E, E)-2,4$-Decadienal & {$[23]$} & 1314 & 1312 & 31.744 & - & - & - & - & 1.4 & - & - & - & - & - \\
\hline Tetradecanal & [23] & 1611 & 1613 & 40.576 & - & - & 1.6 & - & - & - & 1.1 & - & - & - \\
\hline \multicolumn{15}{|l|}{ Ketone } \\
\hline 1-Octen-3-one & [40] & 977 & 974 & 14.650 & - & - & - & - & 0.1 & - & 0.1 & - & - & - \\
\hline 3-Octanone & [26] & 979 & 981 & 15.000 & - & - & - & - & - & - & 0.9 & - & - & - \\
\hline Undecen-2-one & [26] & 1293 & 1295 & 28.418 & - & - & - & - & - & - & 3.1 & - & - & - \\
\hline (Z)- $\beta$-Damascenone & {$[22]$} & 1347 & 1345 & 31.944 & - & - & 2.5 & - & 4.3 & - & - & - & - & - \\
\hline$(E)$ - $\beta$-Damascenone & [29] & 1383 & 1385 & 32.019 & 1.6 & - & - & - & - & - & 3.0 & - & - & - \\
\hline 2-Pentadecanone & [41] & 1696 & 1692 & 42.843 & - & - & 26.7 & - & 12.2 & - & 7.2 & - & - & - \\
\hline \multicolumn{15}{|l|}{ Alcohols } \\
\hline 2-Methyl-1-butanol & [37] & 733 & 736 & 7.110 & - & 0.3 & - & - & - & - & - & - & - & - \\
\hline (Z)-3-Hexenol & [40] & 864 & 861 & 10.262 & - & 7.7 & - & - & - & - & - & - & - & 91.3 \\
\hline n-Hexanol & [40] & 870 & 872 & 10.610 & - & - & - & - & - & - & - & 12.0 & - & 0.1 \\
\hline 1-Octen-3-ol & [29] & 979 & 978 & 14.765 & 6.6 & - & 26.1 & - & 11.8 & - & 4.0 & 5.7 & 2.3 & 0.1 \\
\hline Octan-3-ol & [22] & 993 & 995 & 15.450 & - & - & 0.5 & - & - & - & 5.3 & - & 0.3 & - \\
\hline Nonanol & [40] & 1168 & 1169 & 23.188 & - & - & - & - & - & - & 1.4 & - & - & - \\
\hline \multicolumn{15}{|l|}{ Others } \\
\hline 2-Ethyl furan & [42] & 728 & 724 & 6.572 & - & 17.6 & - & 19.5 & - & 7.2 & - & 14.8 & - & 1.0 \\
\hline $\begin{array}{l}\text { 1-Ethyl-3- } \\
\text { methylbenzene }\end{array}$ & [43] & 968 & 967 & 14.511 & 1.2 & - & - & - & - & - & - & - & - & - \\
\hline 2-Pentylfuran & [29] & 993 & 992 & 15.265 & - & - & 0.6 & 0.1 & 1.8 & - & 1.8 & 4.7 & - & - \\
\hline n-Hexadecanoic acid & [26] & 1959 & 1955 & 51.591 & 0.1 & - & - & - & - & - & - & - & 0.1 & - \\
\hline
\end{tabular}

* Retention Index of references; ${ }^{a}$ Retention Index calculated from retention times relative to that of n-alkane $\left(\mathrm{C}_{6}-\mathrm{C}_{32}\right)$ series. ${ }^{b}$ Percentages obtained by FID peak-area normalization; A1: Clevenger of S. chrysantha; A2: SPME of S. chrysantha; B1: Clevenger of S. kotschyana; B2: SPME of S. kotschyana; C1: Clevenger of S. olympica; C2: SPME of S. olympica; D1: Clevenger of S. cinerascens; D2: SPME of S. cinerascens; E1: Clevenger of $S$. zuvandica; E2: SPME of $S$. zuvandica. 
Table 3. The chemical class distribution of the volatile organic components of the five Scrophularia species.

\begin{tabular}{|c|c|c|c|c|c|c|c|c|c|c|c|c|c|c|c|c|c|c|c|c|}
\hline \multirow[t]{3}{*}{ Chemical class } & \multicolumn{2}{|c|}{ A1 } & \multicolumn{2}{|c|}{ A2 } & \multicolumn{2}{|c|}{ B1 } & \multicolumn{2}{|c|}{ B2 } & \multicolumn{2}{|c|}{$\mathrm{C} 1$} & \multicolumn{2}{|c|}{$\mathrm{C} 2$} & \multicolumn{2}{|c|}{ D1 } & \multicolumn{2}{|c|}{ D2 } & \multicolumn{2}{|c|}{ E1 } & \multicolumn{2}{|c|}{ E2 } \\
\hline & $\mathrm{NC}$ & $\%^{b}$ & $\mathrm{NC}$ & $\%^{b}$ & $\mathrm{~N}$ & $\%^{b}$ & $\mathrm{~N}$ & $\%^{b}$ & $\mathrm{~N}$ & $\%^{\mathrm{b}}$ & $\mathrm{NC}$ & $\%^{b}$ & $\mathrm{NC}$ & $\%^{b}$ & $\mathrm{~N}$ & $\%^{\mathrm{b}}$ & $\mathrm{N}$ & $\%^{b}$ & $\mathrm{~N}$ & $\%^{\mathrm{b}}$ \\
\hline & $\mathrm{a}$ & & $\mathrm{a}$ & & $\mathrm{C}^{\mathrm{a}}$ & & $\mathrm{C}^{\mathrm{a}}$ & & $\mathrm{C}^{\mathrm{a}}$ & & $\mathrm{a}$ & & $\mathrm{a}$ & & $\mathrm{C}^{\mathrm{a}}$ & & $\mathrm{C}^{\mathrm{a}}$ & & $\mathrm{C}^{\mathrm{a}}$ & \\
\hline $\begin{array}{l}\text { Monoterpene } \\
\text { hydrocarbons }\end{array}$ & 2 & 6.8 & 2 & 8.0 & 1 & 0.1 & - & - & 3 & 3.6 & 8 & 47.6 & 1 & 6.4 & - & - & 3 & 6.9 & 5 & 1.7 \\
\hline $\begin{array}{l}\text { Oxygenated } \\
\text { monoterpene }\end{array}$ & 5 & 76.6 & 1 & 3.8 & - & - & - & - & 3 & 13.5 & 3 & 18.6 & 2 & 2.7 & - & - & 7 & 84.4 & 2 & 0.6 \\
\hline $\begin{array}{l}\text { Sesquiterpene } \\
\text { hydrocarbons }\end{array}$ & 2 & 3.4 & - & - & - & - & - & - & - & - & - & - & - & - & - & - & 2 & 2.3 & - & - \\
\hline $\begin{array}{l}\text { Oxygenated } \\
\text { sesquiterpenes }\end{array}$ & - & - & - & - & - & - & - & - & 1 & 2.1 & - & - & 1 & 5.4 & - & - & 2 & 0.6 & - & - \\
\hline $\begin{array}{l}\text { Oxygenated } \\
\text { diterpenes }\end{array}$ & - & - & - & - & 1 & 11.5 & - & - & 1 & 12.0 & - & - & 1 & 7.9 & - & - & - & - & - & - \\
\hline $\begin{array}{l}\text { Terpene } \\
\text { related } \\
\text { compounds }\end{array}$ & 1 & 1.0 & - & - & 3 & 2.7 & - & - & 3 & 6.4 & - & - & 3 & 6.9 & - & - & - & - & - & - \\
\hline $\begin{array}{l}\text { Aliphatic } \\
\text { hydrocarbons }\end{array}$ & - & - & 1 & 0.6 & 3 & 18.6 & - & - & 4 & 11.6 & 1 & 2.9 & 3 & 7.6 & 1 & 1.7 & - & - & - & - \\
\hline Aldehyde & 1 & 2.3 & 7 & 61.9 & 8 & 10.0 & 13 & 80.3 & 8 & 19.2 & 12 & 23.6 & 8 & 36.2 & 10 & 61.0 & 3 & 3.0 & 9 & 5.1 \\
\hline Ketone & 1 & 1.6 & - & - & 2 & 29.2 & - & - & 3 & 16.6 & - & - & 4 & 13.4 & - & - & - & - & - & - \\
\hline Alcohols & 1 & 6.6 & 2 & 8.0 & 2 & 26.6 & - & - & 1 & 11.8 & - & - & 4 & 11.6 & 2 & 17.7 & 2 & 2.6 & 3 & 91.5 \\
\hline Other & 2 & 1.3 & 1 & 17.6 & 1 & 0.6 & 2 & 19.6 & 1 & 1.8 & 1 & 7.2 & 1 & 1.8 & 2 & 19.5 & 1 & 0.1 & 1 & 1.0 \\
\hline Total & 15 & 99.6 & 14 & 99.9 & 21 & 99.3 & 15 & 99.9 & 28 & 98.6 & 25 & 99.9 & 28 & 99.9 & 15 & 99.9 & 20 & 99.9 & 20 & 99.9 \\
\hline
\end{tabular}

${ }^{a}$ NC: Number of compounds. ${ }^{b} \%$ Area of compounds; A1: Clevenger of S. chrysantha; A2: SPME of S. chrysantha; B1: Clevenger of S. kotschyana; B2: SPME of $S$. kotschyana; C1: Clevenger of S. olympica; C2: SPME of S. olympica; D1: Clevenger of S. cinerascens; D2: SPME of S. cinerascens; E1: Clevenger of S. zuvandica; E2: SPME of $S$. zuvandica. 
Investigations on the other Scrophularia species have shown that the oxygenated terpene and monoterpene compounds are abundant and the results are consistent with the reported other species of the genus [11-14]. Fatty acids were not found in the species that we studied, however they were abundant in the essential oil composition of $S$. ningpoensis which has been intensively used and has patented preparations in Chinese folk medicine [12]. S. kotschyana was described as "strongly foetid" in the monograph of flora of Turkey [1]. Its unpleasant smell was also observed by us during the collection of these plants. As a result of this study, isovaleraldehyde was found to be the major compound in the SPME of the S. cinerascens, S. chrysantha, and S. kotschyana in a ratio of $13.6 \%$, $37.1 \%$, and $27.9 \%$, respectively (Table 3 ). Since the significant odor of isovaleraldehyde was reported before, it could be responsible for the characteristic fragrance that was indicated in the flora of Turkey $[1,21]$.

The antimicrobial activity for the essential oils was tested in vitro using the agar-well diffusion method against the microorganisms seen in Table 4. None of the essential oils showed antibacterial activity against Gram-negative bacteria. The essential oils of S.chrysantha, S. kotschyana S. olympica, S.cinerascens and $S$. zuvandica showed weak antimicrobial activity against $B$. cereus and all of the tested essential oils found to have moderate activity against $M$. tuberculosis within the Gram-positive bacteria. Tuberculosis of the lymphatic glands which was caused by the bacterium M. tuberculosis, has affected humans for thousands of years [43]. Considering the remarkable activity of all of the studied species against $M$. tuberculosis, it is noteworthy that the name of the genus Scrophularia is reported to come from its usage in scrofulous swellings which are the results of a type of tuberculosis $[4,44]$.

A few studies conducted on the antimicrobial activities of essential oils of Scrophularia species. The essential oil of $S$. amplexicaulis has previously been shown to have comparable antibacterial activity with the positive control ampicillin against Staphylococcus aureus [14]. The insecticidal activity of the essential oil of $S$. oxysepala was studied and found to be time and

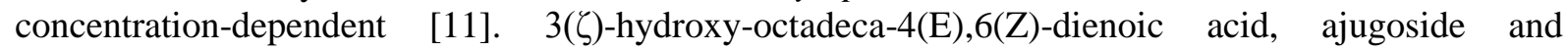
scropolioside B which were isolated from $S$. desertii, were reported to have moderate antibacterial activity against strains of multidrug and methicillin-resistant $S$. aureus (MRSA) and a panel of rapidly growing mycobacteria (MIC values ranging from 32 to $128 \mu \mathrm{g} / \mathrm{ml}$ ) [45].

The comparative analysis of the volatile chemical profiles of the five Scrophularia species proved that they differ markedly in their volatile chemical profiles and in their antimicrobial activity.

Table 4. Screening for antimicrobial activity of the essential oils from Scrophularia species $(\mu \mathrm{g} / \mu \mathrm{L})$.

\begin{tabular}{|c|c|c|c|c|c|c|c|c|c|c|}
\hline \multirow{2}{*}{ Plant species } & \multirow{2}{*}{$\begin{array}{c}\text { Stoc. Sol. } \\
(\mu \mathrm{g} / \mu \mathrm{L})\end{array}$} & \multicolumn{9}{|c|}{ Microorganisms and Inhibition Zone (mm) } \\
\hline & & Ec & Yp & $\mathrm{Pa}$ & $\mathrm{Sa}$ & $\mathrm{Ef}$ & $\mathrm{Bc}$ & Ms & $\mathrm{Ca}$ & $\mathrm{Sc}$ \\
\hline S. chrysantha & $62 / 800$ & - & - & - & - & - & 8 & 10 & - & - \\
\hline S. kotschyana & $145 / 800$ & - & - & - & - & - & - & 13 & - & - \\
\hline S. olympica & $89 / 100$ & - & - & - & - & - & 6 & 14 & - & - \\
\hline S. cinerascens & $100 / 500$ & - & - & - & - & - & 6 & 14 & 6 & - \\
\hline S. zuvandica & $44 / 200$ & - & - & - & - & - & 8 & 12 & 8 & 6 \\
\hline Ampicillin & 10000 & 10 & 10 & 18 & 10 & 35 & 15 & - & - & - \\
\hline Streptomycin & 10000 & - & - & - & - & - & - & 35 & - & - \\
\hline Fluconazole & 2000 & - & - & - & - & - & - & - & 25 & 25 \\
\hline
\end{tabular}

Ec: E. coli ATCC 35218, Yp: Y. pseudotuberculosis ATCC 911, Pa: P. aeruginosa ATCC 27853, Sa: S. aureus ATCC 25923, Ef: E. faecalis ATCC 29212, Bc: B. cereus 709 Roma, Ms: M. smegmatis ATCC607, Ca: C. albicans ATCC 60193, Sc: S. cerevisiae RSKK 251, (-): activity not detected at tested concentration.

\section{References}

[1] S. S. Lall and R. R. Mill (1978). Scrophularia L. In: Flora of Turkey and the East Aegean Islands, ed: P. H. Davis, Edinburgh University Press, Edinburgh, Volume 6, pp. 603-647. 
[2] A. O. Olivencia (2009). Scrophularia L. In: Flora Iberica, eds: C. Benedí, E. Rico, J. Güemes, A. Herrero, Real Jardín Botánico, CSIC, Madrid, 97-134.

[3] M. E. Uzunhisarcıkl1, E. D. Güneri, F. Özbek and B. Bilgili, (2015). Scrophularia lucidaifolia (Scrophulariaceae), a new species from Turkey, Phytotaxa, 204, 95-98.

[4] M. E. Uzunhisarcıklı (2012) Scrophularia. In: Türkiye Bitkileri Listesi (Damarlı Bitkiler). eds: A. Güner, S. Aslan, T. Ekim, M. Vural, M.T. Babaç, Nezahat Gökyiğit Botanik Bahçesi ve Flora Araştırmaları Derneği Yayını, İstanbul.

[4] U. Quattrocchi (1999). CRC World Dictionary of Plant Names: Common Names, Scientific Names, Eponyms, Synonyms, and Etymology, CRC Press, USA.

[5] E. Altundağ and M. Öztürk (2011). Ethnomedicinal studies on the plant resources of East Anatolia, Turkey, Proced. Soc. Behav. Sci. 19, 756-777.

[6] J. A. Duke, E. S. Ayensu (1985). Medicinal Plants of China. Reference Publ., Inc. Algonac. Michigan.

[7] A. M. Gençler Özkan and M. Koyuncu (2005). Traditional medicinal plants used in Pınarbaş1 area (Kayseri-Turkey), Turk. J. Pharm. Sci. 2(2), 63-82.

[8] M. C. Loi, F. Poli, G. Sacchetti, M. B. Selenu and M. Ballero (2004). Ethnopharmacology of Ogliastra (Villagrande Strisaili, Sardinia, Italy), Fitoterapia. 75, 277-295.

[9] E. Sezik, E. Yeşilada, G. Honda, Y. Takaishi, Y. Takeda and T. Tanaka (2001). Traditional medicine in Turkey X. Folk medicine in Central Anatolia, J. Ethnopharmacol. 75, 95-115.

[10] E. Uzun, G. Sarıyar, A. Adsersen, B. Karakoç, G. Ötük, E. Oktayoğlu and S. Pırıldar (2004). Traditional medicine in Sakarya province (Turkey) and antimicrobial activities of selected species, $J$. Ethnopharmacol. 95, 287-296.

[11] A. Pasdaran, L. Nahar, S. Asnaashari, S. D. Sarker and A. Delazar (2013). GC-MS analysis, free-radical scavenging and insecticidal activities of essential oil of Scrophularia oxysepala Boiss, Pharm Sci. 19, $1-5$.

[12] M. Miyazawa and Y. Okuno (2003). Volatile components from the roots of Scrophularia ningpoensis Hemsl, Flavour Fragr. J. 18, 398-400.

[13] P. Asgharian, F. H. Afshar, S. Asnaashari, S. B. Moghaddam, A. Delazar (2016). The seasonal variations of the chemical composition of essential oil obtained from Scrophularia frigida, J. Nat. Pharm. Prod. 11, 1-5.

[14] A. Pasdaran, A. Delazar, H. Nazemiyeh, L. Nahar and S. D. Sarker (2012) Chemical composition, and antibacterial (against Staphylococcus aureus) and free-radical-scavenging activities of the essential oil of Scrophularia amplexicaulis Benth., Rec Nat Prod. 6, 350-355.

[15] G. Renda, G. Tosun and N. Yaylı (2016) SPME GC/MS analysis of three Ornithogalum L. species from Turkey, Rec Nat Prod. 10, 497-502.

[16] B. Yayli, G. Tosun, M. Karaköse, G. Renda and N. Yayli (2014) SPME/GC-MS analysis of volatile organic compounds from three Lamiaceae species (Nepeta conferta Hedge \& Lamond, Origanum onites L. and Satureja cuneifolia Ten.) growing in Turkey, Asian J Chem. 26, 2541-2544.

[17] A. L. Barry, W. Craig, H. Nadler, L. B. Reller, C. C. Sanders and J. M. Swenson (1999). Methods for determining bactericidal activity of antimicrobial agents; approved guideline, National committee for clinical laboratory standard M26-A, NCCLS. 19(18), 1-29.

[18] A.Nagaraj, M.Sunitha, L.S.Rao, M.V. Devi and C.S.Reddy (2015).Synthesis and biological evaluation of 3-benzyl/piperazino-methyl-1,2,3-triazol-4-yl)-2,3-dihydro-1,3,4-thiadiazole-2-thione, Org.Commun. 8, 70-77

[19] B. Sreedhar, T.V. Reddy, C.N. Raju and G.V.S. Reddy (2016). Design, synthesis, characterization and bioassay of novel carboxamide derivatives of celecoxib, Org. Commun. 9, 54-64

[20] G. L. Woods, B. A. Brown-Elliott, E. P. Desmond, G. S. Hall, L. Heifets, G. E. Pfyffer, J. C. Ridderhof, R. J. Wallace, N. C. Warren and F. G. Witebsky (2003). Susceptibility testing of Mycobacteria nocardiae, and other aerobic actinomycetes; Approved Standard, NCCLS document, M24-A. 23(18), 161.

[21] OECD SIDS (2010) 3-methylbutanal, SIDS Initial Assessment Report for $10^{\text {th }}$ SIAM, UNEP Publications, Tokyo, Japan, 15-17 March 2000.

[22] R.P. Adams (1995). Identification of Essential Oil Components by Gas Chromatography/Mass Spectrometry. Allured Publishing Corporation, Carol Stream, IL.

[23] C. E. Quijano, G. Salamanca and J. A. Pino (2007). Aroma volatile constituents of Colombian varieties of mango (Mangifera indica L.), Flavour Fragr J. 22, 401-406.

[24] K. Veres, B. Csupor-Loffler, A. Lazarand and J. Holmann (2012). Antifungal activity and composition of essential oils of Conyza canadensis herbs and roots, The Sci. World J. 1-5. 
[25] D. García, A. Alvarez, P. Tornos, A. Fernandez and T. Sáenz (2002). Gas chromatographic-mass spectrometry study of the essential oils of Pimenta racemosa var. terebinthina and $P$. racemosa var. grisea, Z. Naturforsch. 57c, 449-451.

[26] R. P. Adams, J.A. Morris, R.N. Pandey and A.E. Schwarzbach (2005). Cryptic speciation between Juniperus deltoides and Juniperus oxycedrus (Cupressaceae) in the Mediterranean, Biochem. Syst. Ecol. 33, 771-787.

[27] E. E. Stashenko, B. E. Jaramillo and J. R. Martínez (2003). Comparación de la composición química y de la actividad antioxidante in vitro de los metabolitos secundarios volátiles de plantas de la familia verbenaceae, Rev. Acad. Colomb. Cienc. Exactas. Fis. Nat. 27, 579-597.

[28] F. Senatore, N. Apostolides Arnold and F. Piozzi (2004). Chemical composition of the essential oil of Salvia multicaulis var. simplicifolia Boiss. growing wild in Lebanon, J. Chromatogr. A. 1052, 1-2, 237 240.

[29] N. Kahriman, G. Tosun, H. Genc and N. Yayli (2010). Comparative essential oil analysis of Geranium sylvaticum estracted by hydrodistillation and microwave distillation, Turk. J. Chem. 34, 969-976.

[30] K. Chang, G. Kim (2012). Volatiles of Chrysanthemum zawadskii var. latilobum K, Prev. Nutr. Food. Sci. 17(3), 234-238.

[31] N. Bouzouita, F. Kachouri, M. Hamdi and M. M. Chaabouni (2003). Antimicrobial activity of essential oils from Tunisian aromatic plants, Flavour Fragr. J. 18, 380-383.

[32] K. Javidnia, R. Miri, M. Kamalinejad, H. Sarkarzadeh and A. Jamalian (2004). Chemical composition of the essential oils of Anthemis altissima L. grown in Iran, Flavour Frag.r J. 19(3), 213-216.

[33] B. Siegmund, K. Derler and W. Pfannhauser (2004). Chemical and sensory effects of glass and laminated carton packages on fruit juice products. Still a controversial topic, Lebensm. Wiss. Technol. 37, 481-488.

[34] D. J. Daferera, B. N. Ziogas and M. G. Polissiou (2003). The effectiveness of plant essential oils on the growth of Botrytis cinerea, Fusarium sp. and Clavibacter michiganensis subsp. michiganensis, Crop. Prot. 22, 39-44.

[35] G. Ferretti, F. Maggi and B. Tirillini (2005). Essential oil composition of Hypericum richeri Vill. from Italy, Flavour Fragr. J. 20, 295-298.

[36] A. I. Carrapiso, J. Ventanas and C. García (2002). Characterization of the most odor-active compounds of Iberian ham headspace, J. Agric. Food. Chem. 50, 1996-2000.

[37] B. Siegmund and M. Murkovic (2004). Changes in chemical composition of pumpkin seeds during the roasting process for production of pumpkin seed oil (Part 2: volatile compounds), Food Chem. 84, 367374.

[38] J. Y. Zhao, J. M. Liu, X. Y. Zhang, Z. J. Liu, T. Tsering, Y. Zhong and P. Nan (2006). Chemical composition of the volatiles of three wild Bergenia species from western China, Flavour Fragr. J. 21, 431-434.

[39] S.D. Hatipoglu, N. Zorlu, T. Dirmenci, A.C. Goren, T. Ozturk and G. Topcu (2016). Determination of volatile organic compounds in fourty five Salvia Species by thermal desorption-GC-MS technique, Rec. Nat. Prod. 10, 659-700.

[40] K. Mahattanatawee, K. L. Goodner and E. A. Baldwin (2005). Volatile constituents and character impact compounds of selected Florida's tropical fruit, Proc. Fla. State. Hort. Soc. 118, 414-418.

[41] D. Ansorena, I. Astiasarán and J. Bello (2000). Influence of the simultaneous addition of the protease flavourzyme and the lipase novozyme $677 \mathrm{BG}$ on dry fermented sausage compounds extracted by SDE and analyzed by GC-MS, J. Agric. Food. Chem. 48, 2395-2400.

[42] M. J. Jordán, C. A. Margaría, P. E. Shaw and K. L. Goodner (2002). Aroma active components in aqueous kiwi fruit essence and kiwi fruit puree by GC-MS and multidimensional GC/GC-O, J. Agric. Food. Chem. 50, 5386-5390.

[43] M. Stavri, K. T. Mathew and S. Gibbons (2006). Antimicrobial constituents of Scrophularia deserti, Phytochem. 67, 1530-1533.

[44] D. Schlossberg (2011). Tuberculosis and Nontuberculous Mycobacterial Infections, ASM Press, New York.

[45] Y. Zhao, J. Li, Y. Xu, H. Duan, W. Fan and G. Zhao (2008). Extraction, preparation and identification of volatile compounds in Changyu XO brandy, Chinese J. Chromatogr. 26, 212-222.

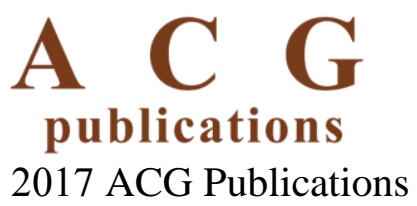

